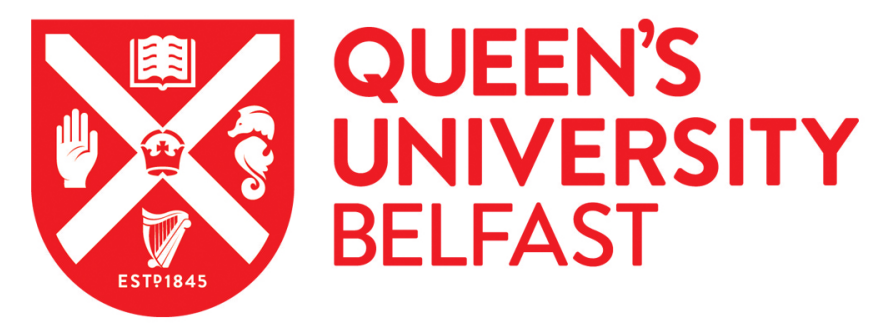

\title{
Review: The meaning of coping for kidney transplant recipients: a phenomenological study
}

Carswell, C., \& Noble, H. (2018). Review: The meaning of coping for kidney transplant recipients: a phenomenological study. Journal of Research in Nursing. https://doi.org/10.1177/1744987118786096

Published in:

Journal of Research in Nursing

Document Version:

Peer reviewed version

Queen's University Belfast - Research Portal:

Link to publication record in Queen's University Belfast Research Portal

Publisher rights

(C) 2018 The Authors.

This work is made available online in accordance with the publisher's policies. Please refer to any applicable terms of use of the publisher.

\section{General rights}

Copyright for the publications made accessible via the Queen's University Belfast Research Portal is retained by the author(s) and / or other copyright owners and it is a condition of accessing these publications that users recognise and abide by the legal requirements associated with these rights.

Take down policy

The Research Portal is Queen's institutional repository that provides access to Queen's research output. Every effort has been made to ensure that content in the Research Portal does not infringe any person's rights, or applicable UK laws. If you discover content in the Research Portal that you believe breaches copyright or violates any law, please contact openaccess@qub.ac.uk. 


\title{
Review: The meaning of coping for kidney transplant recipients: a phenomenological study
}

\author{
Claire Carswell \\ PhD student, School of Nursing and Midwifery, Queen's University Belfast, Northern Ireland
}

Helen Noble

Lecturer, School of Nursing and Midwifery, Queen's University Belfast, Northern Ireland

End-stage kidney disease (ESKD) is growing in prevalence globally, potentially as a consequence of increasing rates of diabetes mellitus and hypertension. Advancements in renal replacement therapies have significantly increased life expectancy among patients with ESKD, with kidney transplantation being the most common modality used. Iran's non-related donor renal transplant programme has resulted in a significant increase in the number of patients receiving a kidney transplant, and currently their transplantation rates are comparable to those of developed countries (Mousavi et al., 2014). There is increasing acknowledgement of the difficulties associated with adaptation to renal replacement therapies, and the need for patients to develop effective coping strategies to manage these difficulties. The reviewed study examines the meaning of coping for kidney transplant recipients in Iran using a hermeneutic phenomenological approach. The identified themes focus primarily on adherence to the treatment regime associated with transplantation, while highlighting the importance of social support and spirituality for Iranian patients. Consequently, the authors reject commonly used theories of stress and coping, such as Lazarus and Folkman's model of stress (Lazarus and Folkman, 1984), as they are unable to account for the use of religion as a means of coping with transplantation. This research supports studies that have identified the importance of spirituality in other clinical populations, as religion is an important component of coping for patients with cancer in Iran (Sharif et al., 2018). This has implications for practice as spirituality is an underaddressed need within holistic care, with Iranian nurses reporting they feel unqualified and have insufficient knowledge to address patients' spiritual needs (Zakaria Kiaei et al., 2015).

Although the researchers identify a spirituality theme, other themes predominantly centre on behavioural, lifestyle and attitudinal changes associated with kidney transplant, and do not explore emotional wellbeing and related coping strategies. This may reflect a cultural difference, as studies conducted in Europe place a significant emphasis on emotional wellbeing, have identified emotional difficulties associated with adaptation post-transplant (Schipper et al.,2014), and have found that managing stressful emotions is the most difficult part of the adaptation process (Schmid-Mohler et al., 2014). However, Iranian patients receiving haemodialysis may find emotional support more important than physical support (Shahgholian and Yousefi, 2015); therefore, it would be beneficial to explore this subject further.

While the authors conceptualise coping in kidney transplantation as acceptance of a new way of life, it is important for research to examine how this acceptance can be achieved. The reviewed study reveals the role that spirituality plays in the lives of patients with ESKD in Iran following kidney transplantation, and highlights the importance of including cultural and religious considerations in 
person-centred care. Consequently, the reviewed study, and other related studies, can be used to inform training for nurses who feel they do not have the necessary knowledge to incorporate spirituality into person-centred care.

\section{$\underline{\text { References }}$}

Lazarus RS and Folkman S (1984) Stress, Appraisal and Coping. New York: Springer.

Mousavi SSB, Soleimani A and Mousavi MB (2014) Epidemiology of end-stage renal disease in Iran: A review article. Saudi Journal of Kidney Diseases and Transplantation 25(3): 697.

Schipper K, Abma TA, Koops C, et al. (2014) Sweet and sour after renal transplantation: A qualitative study about the positive and negative consequences of renal transplantation. British Journal of Health Psychology 19(3): 580-591.

Schmid-Mohler G, Scha" fer-Keller P, Frei A, et al. (2014) A mixed-method study to explore patients' perspective of self-management tasks in the early phase after kidney transplant. Progress in Transplantation 24(1): 8-18.

Shahgholian N and Yousefi $\mathrm{H}$ (2015) Supporting hemodialysis patients: A phenomenological study. Iranian Journal of Nursing and Midwifery Research 20(5): 626.

Sharif SP, Lehto RH, Nia HS, et al. (2018) Religious coping and death depression in Iranian patients with cancer: Relationships to disease stage. Supportive Care in Cancer. Epub ahead of print. DOI: 10.1007/s00520-018-4088-2 (accessed 15 February 2018).

Zakaria Kiaei M, Salehi A, Moosazadeh Nasrabadi A, et al. (2015) Spirituality and spiritual care in Iran: Nurses' perceptions and barriers. International Nursing Review 62(4): 584-592. 